IRA-International Journal of Applied Sciences

ISSN 2455-4499; Vol.04, Issue 03 (2016)

Institute of Research Advances

Pg. no. 490-505

http://research-advances.org/index.php/IRAJAS

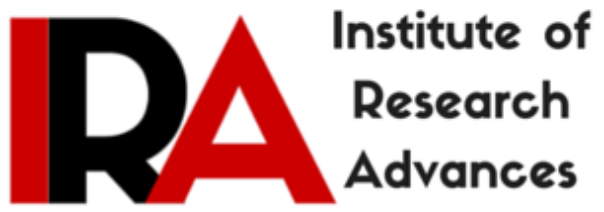

\title{
Assessment of Knowledge, Attitude and Practice towards Hepatitis $B$ among two rural communities of the Anglophone regions in Cameroon
}

\author{
Lem Edith Abongwa ${ }^{1}$, Nyuydzedze Stanley Sunjo ${ }^{1} \&$ Ndifor Glory Afah ${ }^{2}$ \\ ${ }^{1}$ University of Bamenda, Faculty of Science, Department of Biological Sciences, PO Box \\ 39,Bambili, NW. Region, Cameroon. \\ ${ }^{2}$ St Louis University Institute of Health And Biomedical Sciences. Bamenda, N. W. \\ Region, Cameroon.
}

Type of Review: Peer Reviewed.

DOI: http://dx.doi.org/10.21013/jas.v4.n3.p13

\section{How to cite this paper:}

Abongwa, L., Sunjo, N., \& Afah, N. (2016). Assessment of Knowledge, Attitude and Practice towards Hepatitis B among two rural communities of the Anglophone regions in Cameroon. IRA-International Journal of Applied Sciences (ISSN 2455-4499), 4(3), 490505. doi:http://dx.doi.org/10.21013/jas.v4.n3.p13

(C) Institute of Research Advances

\section{(cc) BY-No}

This work is licensed under a Creative Commons Attribution-Non Commercial 4.0 International License subject to proper citation to the publication source of the work.

Disclaimer: The scholarly papers as reviewed and published by the Institute of Research Advances (IRA) are the views and opinions of their respective authors and are not the views or opinions of the IRA. The IRA disclaims of any harm or loss caused due to the published content to any party. 


\section{ABSTRACT}

Viral hepatitis, especially those caused by hepatitis $B$ virus $(H B V)$, represents a worldwide significant cause of morbidity and mortality affecting about 2 billion people worldwide. Prevention against hepatitis $B(H B)$ is proportional to the knowledge, attitude and practice (KAP) of the people. This study seeks to assess the KAP towards HB in two rural areas of the Anglophone regions in Cameroon from the May 2014 of January 2015 using pre-designed and pre-tested, semi- structured questionnaire. Any correct or positive answers was given one point and zero for a no or negative answer. The response rate was 612 (87.4\%). This study revealed that mean (SD) KAP was $14.4(3.7 \%), 4.7(1.1 \%)$ and $3.8(1.2 \%)$ respectively. Thus majority of the respondents had low knowledge 354(57.9\%), high positive attitude 334(54.6\%) and low poor practice 149(24.3\%) regarding HB. Excellent knowledge was expressed only by 38(6.2\%) respondents. A univariate analysis of Knowledge, showed a significant difference $(p<0.05)$ in place, sex, age group, occupation, level of education and monthly income while for attitude a significant difference $(p<0.05)$ was seen only in place and for practices a significant difference $(p<0.05)$ was seen in the place, marital status, occupation, level of education and monthly income. A linear correlation revealed a non significant positive correlation between knowledge and attitude $(r=-0.003, p=0.12)$, a significantly positive correlation between knowledge and practice $(r=0.28, p=0.00)$ and a significantly positive correlation in attitude and Practice $(r=0.27, p=0.00)$.

Key words: Hepatitis B, Knowledge, Attitude and Practice

\section{Introduction}

Hepatitis B virus (HBV) infection is a major health problem worldwide owing to its high prevalence and significant morbidity and mortality [1]. Hepatitis B (HB) is a potentially life-threatening liver infection caused by the hepatitis B virus [2] and can cause chronic infection that is responsible for about $80 \%$ of all cases of cirrhosis and liver cancer [3].

About 2 billion people worldwide have been infected with the virus and about 240 million people are chronically infected as defined by HB surface antigen positive and more than 780,000 people die every year due to complications of HB [1]. This high prevalence rate with its consequences make HBV infection a disease of major public health importance worldwide [1,4].

HBV is transmitted by percutaneous injuries or per mucosal exposure to infectious blood and blood products and can survive outside the body for at least 7 days making it 50 to 100 times more infectious than HIV [5, 6]. In Cameroon, recent studies reported HBV prevalence rates as high as 10.1- 12.1\% among blood donors in hospital blood banks [7] and 7.7\% among pregnant women [8]. In neighboring Nigeria HBV prevalence ranges from 9-39\% [3,9] while in Asia it ranges from 5-10\% in the adult population $[6,10]$. As such the prevalence of HBV infection varies, depending on a number of factors which includes the geographical region, host factors as well as environmental and behavioral factors [3, $11]$.

Prevention is the only safe strategy against high prevalence of any disease [12]. Although HBV is preventable [12] and has a vaccine that has proven to be effective in control of HBV infection, the prevalence of the disease is high especially in sub Saharan countries $[3,6,7,12]$. This probably is due to lack of information about the disease $[10,13,14]$. Studies by [2] state that prevention against any disease is proportional to knowledge, attitude and practice (KAP) of the thus KAP survey is a quantitative method that uses predefined questions to access quantitative and qualitative information in relation to a particular disease. KAP surveys reveal misconceptions or misunderstandings that may represent obstacles to the activities that we would like to implement and potential barriers to behavior change [11, 15]. 
KAP studies play an imperative role in determining the ambiguities of a society and are widely used in population reported assessment research worldwide [11]. KAP of the population is usually important because it is a reflective of the importance that is required to control and prevent health related issues by the society [16]. Thus, to control high prevalence of any disease in developing countries like Cameroon, it is essential to prevent transmission, which is primarily caused due to ignorance, incorrect attitude and poor infrastructure $[11,16]$.

Although HBV have common routes of transmission like HIV unfortunately in Cameroon much has been done on HIV and not HBV [17-19]. This account for the low HIV prevalence of $4.3 \%$ [15] compare to the high prevalence of HBV. Considering that HBV is 50 to 100 times more infectious than HIV [5] and symptoms in HBV infection appear only in 35\% of those infected this makes it difficult in identifying exposure to the infection [4] putting the entire community at risk.

Despite the high prevalence of HBsAg in Cameroon, no KAP study has been carried in the communities. This study will help to identify the gaps in knowledge; attitude and practice that will be helpful in planning effective health education campaign on $\mathrm{HB}$.

\section{Materials and Method}

This study is Cross sectional study to evaluate the KAP in a rural communities. The sample size was determine to be 384 using the Population Proportion Sample Size formula $X=Z_{\alpha / 2}{ }^{2}$ p $*(1-\mathrm{p}) / \mathrm{MOE}^{2}$, where $Z_{\alpha / 2}$ is the critical value of the Normal distribution at $\alpha / 2$ (e.g. for a confidence level of $95 \%, \alpha$ is 0.05 and the critical value is 1.96 ), MOE is the margin of error, $\mathrm{p}$ is the sample proportion, and $\mathrm{N}$ is the population size.

Open ended questionnaires were administered to some Inhabitants of Bamendakwe in the northwest region and Ekona in the Southwest region after obtaining their verbal consent from the May 2014 of January 2015. Pre-designed and pre-tested, semi- structured questionnaire items with response options of yes, no, and no idea was developed based on KAP surveys with similar objectives $[11,13]$. Respondents who could read and write filled the form by themselves while those who could not write were assisted.

The questionnaire was grouped into 4 parts; socio demographic (8 questions), knowledge (29 questions), attitude (9 questions), and practice (9 questions). Knowledge is be used to assessed the person's awareness to a disease (causative agent, transmission, symptoms, treatment prevention etc), while attitude is the approach to think, feel and act in a particular way towards HBV and practices entails what a person will do in case he/she has HBV [11].

Any correct or positive answer was given one point and zero for negative answer, I do not know or wrong answer. Knowledge was scored on 29 and classified as poor < 14, good 14-23 and > 21 very good. While practice and attitude was scored on 9 and classified as bad $<5$, good 5-7 and very good $>7$ While attitude was scored on 9 and classified as negative $<5$, and very good $\geq 5$.

Data was entered and double checked in Microsoft Excel and analyze using Statistical Package for Social Sciences (SPSS vs 16.0). Data were presented using descriptive statistics in the form of frequencies and percentages. Chi-square tests were used for categorical variables. A p-value of 0.05 or less was used as cut off level for statistical significance.

\section{Results}

\section{Demographic of study population}

A total of 700 questionnaires were administered, 654 (93.4\%) were received and $612(87.4 \%)$ were considered for the analysis because they were properly filled. The demographicof the study population is 
shown in Table 1. The age range ofthe respondents was 18-90years with mean (SD) of 34.7(14.0) years.The highest respondents 308(50.3\%) were from Ekona in the southwest Region. More female $343(56.0 \%)$ responded to the questionnaires completely.

\section{Knowledge of Viral Hepatitis B:}

The mean (SD) of knowledge score was 14.4(3.7) and ranges from 7-28 points. Out of the 612 participants, 354 (57.9\%) had poor knowledge range while 221 (36.1\%) and $37(6.0 \%)$ showed good and very good Knowledge towards Hepatitis B respectively. Poor knowledge was noticeable in question partaking to the causative microbe, transmission, symptoms and treatment. Less than one quarter of the participants knew that HBV is a viral infection. The mean \pm SD of knowledge toward HB was 10.4 \pm 9.7. Three quarter of the respondents did not know that HB can be transmitted by blood or blood products. Similarly black colored stools, Cirrhosis, liver cancer etc were not known as symptoms of HB. On the other hand $540(88.2 \%)$ participants said that HB had a cure. More than three quarter of the respondents knew that HB can be prevented unfortunately their knowledge on prevention was poor as shown on Table 2 .

\section{Attitude toward HB}

The score ranged of attitude was 2-8points with mean (SD) score of 4.7(1.1).A total of 334 (54.6\%) respondents had a positive attitude and $278(45.4 \%)$ negative attitude toward HB. Of the 612 participants, $425(69.4 \%)$ believed that they can be infected with HB however only $415(67.8 \%)$ were willing to do the test. Seventy $(11.5 \%)$ respondents stated that they will be normal if they were diagnosed positive. On the contrary $13(2.1 \%)$ will be afraid, $253(41.3 \%)$ will be sad and $276(45.1 \%)$ will be surprised. A total of $594(97.1 \%)$ were willing to take the vaccine but unfortunately at a current price of averagely 24,000CFA frs (40USD) only 147(24.0\%)respondents were willing to pay for the vaccine. Of the 612 respondents, 458(74.8) were willing to share or disclose their result to someone. Only 138 (22.5\%) of respondents will go to the hospital immediately after being diagnosed while a majority of the people $329(53.8 \%)$ will wait for the signs and symptoms to manifest before they go to the hospital. In addition $138(22.5 \%)$ respondents will prefer to go to a tradition doctors, $89(14.5 \%)$ to church, 39(6.4\%) will go to a traditional doctor and $17(2.8 \%)$ seek advice from a friend or family member. A total of 474(77.5\%) respondents taught that patients with HBV should be given the last appointment in the hospital while 352(57.5\%) stated that additional precautions will be taken when playing with $\mathrm{HB}$ patients or relatives. Most inhabitants of these two regions 191 (31.2\%) will prefer to watch sport followed by movies 155 (25.3\%), listen to news 128 (20.9\%) and Church programs $90(14.7 \%)$ at their leisure time than to listen to health talks $48(7.8 \%)$. Majority of the respondents $492(80.39 \%)$ were willing to attend a seminar or listen to a talk on HBV if it will be free Table 4.

\section{Practices of Viral Hepatitis B:}

The mean (SD) score for HB related practices was 3.8 (1.2) with a range of 2-7. Generally 463(75.7\%) had poor practices while $149(24.3 \%)$ had good practices among the study participants. Out of 612 participants, only $126(20.6 \%)$ have screened for HBV and 14(2.3\%) have been vaccinated against HBV. Although all the participants $612(100.0 \%)$ asked for screening of blood before transfusion and $558(91.2 \%)$ ask for a new syringe or sharps objects before use, majority of them 578(94.4\%) attain to injured subjects with open wound as shown on table 3. Only 244(39.9\%) of the study participants have either attendeda seminar or listen to a talk on HBV. Of these 98(40.2\%) got the information from a health facility while 79(32.4\%) got it from friends/relative, 38(15.6\%) from Media, and 29(11.9\%) fromschool.

Correlation between knowledge, attitude and practice were interpreted using the following criteria: $0-0.25$ =weak correlation, $0.25-0.5=$ fair correlation, $0.5-0.75=$ good correlation and greater than $0.75=$ excellent correlation [11]. There was an insignificant weak negative correlation between age and knowledge $(\mathrm{r}=-0.03, \mathrm{p}=0.45)$, age and practice $(\mathrm{r}=-0.003, \mathrm{p}=0.94)$ and a weak positive correlation between age and attitude $(\mathrm{r}=0.013, \mathrm{p}=0.75)$. The correlation revealed a weak non significant positive 
linear correlation between knowledge and attitude $(\mathrm{r}=0.06, \mathrm{p}=0.12)$ and a significantly fair positive linear correlation between knowledge and practice $(\mathrm{r}=0.28, \mathrm{p}=0.00)$ and attitude and Practice $(\mathrm{r}=0.27, \mathrm{p}=$ $0.00)$.

A univariate analysis of Knowledge, showed a significant difference $(\mathrm{p}<0.05)$ in place, sex, age group, occupation, level of education and monthly income.Excellent knowledge on HB was recorded in Ekona, among females, respondents of the age group 25- 34 years, the divorced, medical practitioners, persons that have attain tertiary level of education and with the highest monthly income $>150,000 \mathrm{frs}$ as shown on table 5

Looking at attitude a univariate analysis, showed that a significant difference $(p<0.05)$ between negative and positive attitude only in place. However positive attitude toward HB was recorded highest in Ekona, with females, respondents of the age group <25years, the divorced, traders, persons that have never been in school and with monthly income of 50,000-100,000frs as shown on table 6

A univariate analysis on Practice, showed a significant difference $(\mathrm{p}<0.05)$ in the place, marital status, occupation, level of education and monthly income. Good practices on HB was recorded highest in Ekona, with females, respondents of the age group $>44$ years, the divorced, medical practitioners, persons that have attain tertiary level of education and with the highest monthly income $>150,000$ frs as shown on table 7 .

\section{Discussion}

$\mathrm{HBV}$ is a major cause of the dreadful liver diseases, fortunately this virus is preventablewith the use of a safe and effective vaccine [4]. Study on KAP is essential to improve the awareness, on transmission, prevention, importance of early diagnosis for appropriate management. This study to the best of our knowledge is the first comprehensive study carried out in the entire country to obtain KAP towards HB among healthy individuals in a rural communityin an endemic area like Cameroon [20].

Results of the study revealed that a higher population 354 (57.9\%) had poor knowledge on HB. Poor knowledge regarding HB has also been reported in other countries like Pakistan [11], Malaysia [10] and contradicts studies carried in Japan [14], Chinese Canadians [21] and Vietnamese Americans [22]. The most probable reasons could be inadequate health educative programs present in this locality since only $244(39.9 \%)$ of the study participants had listen to health talk on HBV. Secondly 79(32.4\%) got information from Friends/Relatives indicating that there is a great probability of inappropriate information given out. Misconceptions about a disease can eventually lead to stigma, poor prevention or control measures. In addition, poor knowledge recorded can also be attributed to the fact that few participants $176(28.8 \%)$ prefer to listen or watch health related programs. Improved knowledge on HB can be through improved mass media program by broadcasting health talk intermittently within other programs like sports, films, or music.

Although HBV is 50-100 times transmissible than HIV [5] most health campaigned in the country is geared towards HIV and this account for the low prevalence of 4.3\% [15]. Although HIV and HBV shared common transmission and prevention means lack of knowledge on HB transmission may be attributed to high prevalence of HB 7.1\% -16\% [8, 20, 23, 24]seen among different groups of person in Cameroon.

Assessing the knowledge with respect to occupation, 18(90.0\%) of medical practitioners recorded the highest level of very good knowledge (>21 score on 29$)$. This is likely because the disease is studied as a 
school curriculum since healthcare workers are considered to have 2-4 fold occupational risk of hepatitis infections compared to the general population [25]. This study is similar to studies by [3] but contradict those of [26] who reported low level of knowledge among healthcare workers. Taken into consideration that knowledge is usually the first step towards modification of a desirable behavior and prevention of a disease, extensive health education campaign should be provided to the general population especially at the primary level of education since most residents in rural areas usually end up their education at the primary level.

Though we recorded low level of knowledge regarding HBV, more than half $334(54.6 \%)$ of the respondents has a positive attitude contrary to what was reported by [4]and [11] but similar to reports of Shalabyet al., (2007). Since a total of 425 (69.4\%) respondents are aware that they can get HB, this high prevalence mayinfluence their attitude in taking positive actions toward prevention of the disease [5]. A total of $(91.3 \%)$ proposed that all patients should be tested for HBV similar to what is done with HIV. This is important because those who tested negative can be vaccinated against HB. In this study 394 (64.4\%) were willing to take the vaccine if it was free while only $147(24.0 \%)$ were ready to pay the vaccine at the current price of about 40 UDS for the complete dose. This is due to ignorance, or lack of knowledge on the importance on vaccination. Secondly it could beassociated with the lack of initiative on the part of health policy makers in the country to ensure that all eligible persons get vaccinated at free or affordable prices since the available treatment for a hepatitis B virus infection does not provide complete cure.

A total of $458(74.8 \%)$ respondents were willing to share or disclose their result to someone. This is important so that precautions can be taken to prevent the disease or to encourage them to go for screening which could lead to early diagnosis and proper management. However unwillingness to disclose status can be attributed to stigma or social rejection $[4,10,11]$.Since the level of knowledge recorded was low thus a high change of misconceptions about the disease might be very dangerous to the community.

Only $138(22.5 \%)$ of the respondents said they will go to the hospital immediately they are diagnosis positive while $309(50.5 \%)$ said they will go only when signs and symptoms begin to manifest. The rest of respondents $165(27 \%)$ said they will either seek advice from a relative/ friend 39(6.4\%), a traditional healer $17(2.8 \%)$ or go for prayers $109(17.8 \%)$. Most respondents $228(37.2 \%)$ in our study were not aware that signs and symptoms like fever, nausea and vomiting, abdominal discomfort/pain, abdominal distension and dark urine are associated with HBV infection thus will not be able to seek medical attention on time. Secondly since these signs and symptoms are also common to other illness like malaria and typhoid most people will prefer get drugs from community drug stores or by use of local herbs. Early medical attention to a disease can stop the spread of infections to other healthy individuals or reduce deterioration of health condition and thus reduce mortality rates. Failure by the respondents to seek medical attention early can be attributed to lack of knowledge or poverty and has led to additional reasons for seeking alternative methods of treatment. Secondly the proliferation of churches in Cameroon have made people to believe in instant healing miracle as shown over television stations like the Synagogue Church of All Nations or the Christ Embassy Internationalin Nigeria and the Living Faith Ministry or Kingship Ministry in Cameroon.

Most participants $463(75.7 \%)$ of the current study showed poor practice towards HB contrary to reports from Ethiopia [2], Rajasthan [4] and Egypt [27]. Only 126 (20.6\%) have been screened for HBV while only $14(2.3 \%)$ have been vaccinated. Low vaccine uptake has also been reported by [27]. Probably this could be due to lack of information on its importance. In terms of prevention, most respondents 578 (94.4\%) said they will help injured subjects with open wound in other to save life. Similarly all participants $612(100.0 \%)$ said they will ask for screened blood before transfusion. With the exception of 
transfusion of screen blood, majority of the participants were not concerned about the safety measures to prevent HB transmission. Use of transfused blood is a good practice since it also applied to HIV prevention.

A negative correlation between age and knowledge and age and practice is clear indication that at first education of children were not considered important. Secondly younger individuals usually have better opportunity to be educated with better access to information especially through social media. Similarly positive correlation between age and attitude is clear understanding that practical work is easier to apprehend than just knowledge. The positive correlation between knowledge and attitude, between knowledge and practice and between attitude and practice seen in this study has also been reported by [8], [12] and [28]. Thus this study reiterates the relationship between knowledge and practice with respect to infection control measures.

Area of residence, sex, age group, occupation, level of education and monthly income were the significant factors associated knowledge, attitude or practice. However, extensive literature review has shown separate factors such as area of residence [11], level of education [10, 13, 21], age group [10] higher monthly income [13]. These characteristics are usually interrelated as such those with higher education have high incomes, thus better access to educational resources such as internet, that enable them to practice preventive measures. Female had better KAP score than male mostly like because they visit the health facilities than men taking into consideration that most of the respondents got information about HB from health clinics. Similarly KAP score was higher in Ekona than in Bamendankwe most probably because HIV which share similar concepts with HBV is more prevalent in the SWR than in the NWR [15] which has led to more sensitization in this area.

Although data from this study present for the first time KAP of HB in our country however it was conducted only a rural settings and may not be generalized to the entire population. Based on our findings, it is recommended that governmental and non-governmental efforts should be carried out to empower the people with adequate knowledge, effective practice and the right attitude toward HB within all levels of formal and informal school and other programs like church activities, sport etc to raise the awareness on methods of transmission, prevention and self-protection. This should be done through electronic media, newspapers, workshops and as well as intermittently during entertainment programmes like music, film and sport.It is worth mentioning that post intervention studies should be carried out to ensure the right information regarding control and prevention of transmission, has been impacted to the people. It is also recommended that campaign on $\mathrm{HB}$ diagnosis be instituted in all health centers and hepatitis B vaccination be administer to eligible persons for free or affordable prices.

\section{References}

1. WHO. (2015). Hepatitis B. Fact sheet $\mathrm{N}^{\circ} 204$, [retrieved June 23, 2016] Available from, http,//www.who.int/mediacentre/factsheets/fs204/en/

2. Mesfin, Y. M. and Kibret, K. T. (2013). Assessment of Knowledge and Practice towards Hepatitis B among Medical and Health Science Students in Haramaya University, Ethiopia. PLoS ONE, 8(11), e79642.

3. Abiola, O. A., Adebukola, B. A., Badmos, K. B., Adenike, O. L., Abdulrazzaq, O. L. and Quadri, O. A.,(2016). Prevalence of HBsAg, knowledge, and vaccination practice against viral hepatitis B infection among doctors and nurses in a secondary health care facility in Lagos state, Southwestern Nigeria. The Pan African Medical Journal. 23:160. doi:10.11604/pamj.2016.23.160.8710 
4. Baig V., N., Pankaj, K. G., Arvind, K. S. and Madhusudan, S. (2015). Assessment of knowledge, attitude and practice about hepatitis b among clinicians \& medical students: a cross sectional study. National Journal of Community Medicine 6(2): 415 -422.

5. WHO, (2008). Hepatitis B. Factsheet No. 204. Aug., 2008. Médicins du Monde (2011) The KAP Survey Model (Knowledge, Attitudes, and Practices) Contact Institution: http://www.medecinsdumonde.org/Outils/Nous-contacter (link is external) assessed 26 June 24, 2016

6. Al-Gashanin Ali. S. and Mostafa, O. A., (2013). Knowledge, Attitude and Practice of Male Secondary School Students on Hepatitis B in Abha City, Kingdom of Saudi Arabia Medical Journal of Cairo Univsity. 81,(2) 155-161,

7. Frambo,A. J.,Atashili, P. F., Ndumbe, P., (2014). Prevalence of HBsAg and knowledge about hepatitis B in pregnancy in the Buea Health District, Cameroon: a cross-sectional study. BMC Research Notes:7,394.

8. Abongwa. L. E. and Penn, K., (2016). Assessing prevalence and risk factors of hepatitis B surface antigen amongst pregnant women attending antenatal clinic in the northwest region of Cameroon. European Journal of Research in Medical Sciences, 4 (1) 32-43.

9. Emechebe, G. O., Emodi, I. J., Ifekuna, A. N., Ilechukwu, G. C., Igwe, W. C. and Ilechukwu, C. A. (2009). Hepatitis B virus infection in Nigeria-A review. Nigerian Medical Journal. 50(1):1822.

10. Mohamed M., Marashi, S. A., Kabir, A., Taghipour, H. R., Faghihi, K. A. H. and Ghoddoosi, I., (2007). Knowledge, Attitude, and Practice of Surgeons about Blood-Borne Diseases in Iran. Journal of Surgical Research. 22: 4804-4808.

11. UlHaq, M. N., Azmi, A.,Akmal, F.,Saleem, M.,Farooqui, A.,Haseeb,.....Aljadhey, H., (2013). A cross-sectional assessment of knowledge, attitude and practice among Hepatitis-B patients in Quetta, Pakistan, BMC Public Health. 12:692

12. Ghanaei, R., M., Joukar, F. Fatemeh, S., and Zahra, A. R., (2013). Knowledge and attitude of medical science studentstoward hepatitis B and $\mathrm{C}$ infections. International journal of clinical and experimental medicineis . 6(3):197-205

13. Al-Thaqafy, M.S., Balkhy, H.H., Memish, Z., Makhdom, Y.M., Ibrahim, A., Al-Amri, A. and AlThaqafi, A.(2012). Improvement of the low knowledge, attitude and practice of hepatitis B virus infection among Saudi national guard personnel after educational intervention. BMC Research Notes. 30;5:597.

14. Eguchi, H. and Wada k. (2013).Knowledge of HBV and HCV and Individuals' Attitudes Toward HBV- and HCV-Infected Colleagues: A National Cross-Sectional Study among a Working Population in Japan.PLOS ONE 8 (9) e76921.

15. Institut National de la Statistique (INS). (2011). The 2011 Cameroon Demographic and Health Survey and Multiple Indicators Cluster Survey (DHS-MICS 2011). :1-2

16. Das, S., Das, S. K., (2013). Knowledge, attitude and practice of stroke in India versus other developed and developing countries. Annals of Indian Academy of Neurology, 16(4), 488-493.

17. Mbanya, D. N., Zebaze, R., Kengne, A. P.,Minkoulou, E. M., Awah, P. and Beure (2001). Knowledge, attitudes and practices of nursing staff in a rural hospital of Cameroon: how much does the health care provider know about the human immunodeficiency virus/acquired immune deficiency syndrome?. International Nursing Review, 48: 241-249. doi: 10.1046/j.14667657.2001.00090.

18. Sobze, S. M.,Fokam, J., Guetiya, W. R., Russo, G., Onohiol, J. F., Djeunang, D. B., ........ Sanita,I. P.,(2013). Condom perception and prevention of HIV/AIDS infection in Cameroon: appraisal of knowledge, attitudes and practices among level one students of the University of Dschang. Ig Sanita Pubbl 69(2):183-94.

19. Zenebe, Y., Wondemagegn, M., Mulat, Y.,Bayeh, A.,(2014). Sero-prevalence and risk factors of hepatitis B virus and human immunodeficiency virus infection among pregnant women in Bahir Dar city, Northwest Ethiopia: a cross sectional study. BMC Infectious Diseases 14:118. 
20. Andoulo, A. F., Tagni-Sartre, M., Noah, D., Djapa, R., Claude, E. and Ndam, N. (2013). Prevalence of the hepatitis B surface antigen in a population of workers in Cameroon. Open Journal of Gastroenterology, 3(8), 323-327.

21. Wu, C. A., Lin, S. Y., So, S. K. and Chang, E. T.,(2007). Hepatitis B and liver cancer knowledge and preventive practices among Asian Americans in the San Francisco Bay Area California. Asian Pacific journal of cancer prevention 8:127.

22. Taylor, V. M., Choe, J. H., Yasui, Y., Li, L., Burke, N. and Jackson, J. C.,(2005). Hepatitis B awareness, testing, and knowledge among Vietnamese American men and women. Journal of Community Health 30(6):477-90.

23. Zekeng, L., Kaptue, L., (1990). HIV 1 serology and HBsAg and HBeAg carrier status in blood donors at the Yaounde University Hospital, Cameroon. Annales de la SociétéBelge de MédecineTropicale,70, 49-53.

24. Koanga, M. M.L., Louandji, F. S., Fotso, K. H.,Ngono, N. A., (2009). Detection of infectious agents in blood banks in Douala. Cahiers d'Etudeset de RecherchesFrancophones/Santé, 19, 3-8.

25. Cekin, A. H., Cekin, Y., Ozdemir, A., (2013). The level of knowledge of, attitude toward and emphasis given to HBV and HCV infections among healthcare professionals: data from a tertiary hospital in Turkey. International Journal of Occupational Medicine and Environmental Health 26.1: 122-31.

26. Adeiga, A., Omilabu, S. A., Audu, R. A., Sanni, F. A., Lakehinde, G. F. and Balogun, O., (2005).Infant immunization coverage in difficult-toreach area of Lagos metropolis. African Journal of Clinical and Experimental Microbiology. 6(3):227-31.

27. Shalaby, S., Kabbash, I., El-Saleet, G., Mansour, N., Omar, A., El-Nawawy, A., (2007). Hepatitis $\mathrm{B}$ and $\mathrm{C}$ viral infection: prevalence, knowledge, attitude and practice among barbers and clients in Gharbia governorate, Egypt. Eastern Mediterranean Health Journal 2007, 16:10-17.

28. Kabir. A., Tabatabaei, S. V., Khaleghi, S., Agah, S., Kashani, A. H. F., Moghimi,M.,.........Kerahroodi, F. H., (2010). Knowledge, attitudes and practice of Iranian medical specialists regarding hepatitis B and C. Hepatitis Monthly, 10:176-182.

29. Razi, A., Ur-Rahman, R., Naz, S., Ghafoor, F.,Ullah, K. M. A., (2010). Knowledge attitude and practices of university students regarding hepatitis B and C. ARPN Journal of Agricultural and Biological Science 5: 38-43.

\section{Acknowledgment}

The authors would like to thank the study participants for their cooperation.

\section{Competing interests}

The authors have declared no competing interests. 


\section{TABLES}

Table1: Demographics and basic characteristicsof the study respondents $(N=612)$

\begin{tabular}{|c|c|c|c|}
\hline Characteristics & indicators & $\mathbf{N}$ & $\%$ \\
\hline \multirow[t]{2}{*}{ Place } & Bamenda & 304 & 49.7 \\
\hline & Ekona & 308 & 50.3 \\
\hline \multirow[t]{2}{*}{ Sex } & female & 343 & 56.0 \\
\hline & male & 269 & 44.0 \\
\hline \multirow[t]{4}{*}{ Age group } & $<25$ years & 176 & 28.8 \\
\hline & 25- 34 years & 198 & 32.4 \\
\hline & $35-44$ years & 96 & 15.7 \\
\hline & >44years & 142 & 23.2 \\
\hline \multirow[t]{5}{*}{ Marital Status } & concubine & 22 & 37.6 \\
\hline & widow/er & 35 & 46.9 \\
\hline & divorced & 38 & 3.6 \\
\hline & single & 230 & 5.7 \\
\hline & married & 287 & 6.2 \\
\hline \multirow[t]{6}{*}{ Occupation } & medical practitioner & 20 & 8.5 \\
\hline & trader & 32 & 5.7 \\
\hline & civil servant & 35 & 34.5 \\
\hline & student & 52 & 3.3 \\
\hline & Farmer & 211 & 5.2 \\
\hline & technician & 262 & 42.8 \\
\hline \multirow[t]{4}{*}{ Level of education } & none & 296 & 48.4 \\
\hline & secondary & 179 & 29.2 \\
\hline & primary & 105 & 17.2 \\
\hline & tertiary & 32 & 5.2 \\
\hline \multirow[t]{5}{*}{ Income } & $<50,000$ frs & 243 & 39.7 \\
\hline & $50,000-100,000$ frs & 160 & 26.1 \\
\hline & $101,000-150,000$ frs & 137 & 22.4 \\
\hline & $>150,000 \mathrm{frs}$ & 26 & 4.2 \\
\hline & $\mathrm{NA}$ & 46 & 7.5 \\
\hline
\end{tabular}


IRA-International Journal of Applied Sciences

Table 2: Responses of the study participants to Hepatitis B knowledge items

\begin{tabular}{|c|c|c|}
\hline Question & Yes & No \\
\hline Hepatitis B is a Viral Infection & $103(16.8 \%)$ & $509(83.2 \%)$ \\
\hline \multicolumn{3}{|l|}{ Mode of Transmission } \\
\hline Transfusion & $265(43.3 \%)$ & $347(56.7 \%)$ \\
\hline Sharp objects & $158(25.8 \%)$ & $454(74.2 \%)$ \\
\hline Intercourse & $210(34.3 \%)$ & $402(65.7 \%)$ \\
\hline Mother to child & $274(44.8 \%)$ & $338(55.2 \%)$ \\
\hline Sharing household facilities like toilet seat, bed & $298(48.7 \%)$ & $314(51.3 \%)$ \\
\hline Insect bite & $32(5.2 \%)$ & $580(94.8 \%)$ \\
\hline \multicolumn{3}{|l|}{ Symptoms } \\
\hline Black colored stools & $17(2.8 \%)$ & $595(98.2 \%)$ \\
\hline Cirrhosis & $195(31.9 \%)$ & $417(68.1 \%)$ \\
\hline Cough & $402(65.7 \%)$ & $210(34.3 \%)$ \\
\hline Dark Urine & $93(15.2 \%)$ & $519(84.8 \%)$ \\
\hline Distention of abdomen & $221(36.1 \%)$ & $391(63.9 \%)$ \\
\hline Feeling tired (fatigue) & $395(64.5 \%)$ & $217(35.5 \%)$ \\
\hline Fever & $286(46.6 \%)$ & $326(53.3 \%)$ \\
\hline Jaundice & $198(32.4 \%)$ & $414(67.5 \%)$ \\
\hline Nausea and vomiting & $485(79.2 \%)$ & $127(20.8 \%)$ \\
\hline Pain over the liver & $241(39.4 \%)$ & $371(60.6 \%)$ \\
\hline Liver cancer & $332(54.2 \%)$ & $280(45.8 \%)$ \\
\hline \multicolumn{3}{|l|}{ Diagnosis } \\
\hline Do you think HBV can be diagnose in most laboratory & $498(81.4 \%)$ & $114(18.6 \%)$ \\
\hline \multicolumn{3}{|l|}{ Treatment } \\
\hline Can Hepatitis B be self-cured by body & $119(19.4 \%)$ & $(80.6 \%)$ \\
\hline Is Hepatitis B curable/treatable & $540(88.2 \%)$ & $72(11.8 \%)$ \\
\hline Is specific diet is required for the treatment of Hepatitis B? & $129(21.1 \%)$ & $483(78.9 \%)$ \\
\hline \multicolumn{3}{|l|}{ Prevention and control } \\
\hline Could we prevent HB transmission & $561(91.7 \%)$ & $51(8.3 \%)$ \\
\hline Is vaccination available for Hepatitis $B$ & $404(66.0 \%)$ & $208(34.0 \%)$ \\
\hline Proper screening of blood and blood products & $288(47.1 \%)$ & $324(52.9 \%)$ \\
\hline Sterilize needles and medical equipment & $122(19.9 \%)$ & $490(80.1 \%)$ \\
\hline Safer sex practices & $106(17.3 \%)$ & $506(82.7 \%)$ \\
\hline Isolation of patients & $401(65.5 \%)$ & $211(34.5 \%)$ \\
\hline Hepatitis B be test is done before marriage & $337(55.1 \%)$ & $275(44.9 \%)$ \\
\hline
\end{tabular}


Table 3: Proportion of responses toward attitudes items related to hepatitis B

\begin{tabular}{|l|l|l|}
\hline Characteristic & Positive & Negative \\
\hline Do you think you can get Hepatitis B? & $425(69.4 \%)$ & $187(30.6 \%)$ \\
\hline All patients should be tested for HBV & $559(91.3 \%)$ & $53(8.7 \%)$ \\
\hline Hepatitis B test should be done before marriage & $194(31.7 \%)$ & $418(68.3 \%)$ \\
\hline Will you like to do the test & $415(67.8 \%)$ & $197(32.2 \%)$ \\
\hline If you test negative will you like to take the vaccine & $594(97.1 \%)$ & $18(2.9 \%)$ \\
\hline If the vaccine is 10000 will you pay for it & $147(24.0 \%)$ & $465(76.0 \%)$ \\
\hline How will you treat someone with HBV & $138(22.5 \%)$ & $474(77.5 \%)$ \\
\hline Patients with HBV should be given the last appointment & $284(46.4 \%)$ & $328(53.6 \%)$ \\
\hline Have you ever participated in health education program related to HB? & $260(42.5 \%)$ & $352(57.5 \%)$ \\
\hline Give additional precautions when playing with HB patients or relatives & $28(4.6 \%)$ & $584(95.4 \%)$ \\
\hline Isolating infected person from work/daily activity & $201(32.8 \%)$ & $411(67.2 \%)$ \\
\hline Clean utensil or toilet after use by an infected person & & \\
\hline
\end{tabular}


Table 4: Practice related to Hepatitis B prevention

\begin{tabular}{|l|l|l|}
\hline Question & Yes & No \\
\hline Have you screened for HBV & $126(20.6 \%)$ & $486(79.4 \%)$ \\
\hline Are you vaccinated & $14(2.3 \%)$ & $598(97.7 \%)$ \\
\hline Do you avoid meeting Hepatitis B patients? & $119(19.4 \%)$ & $493(80.6 \%)$ \\
\hline Can play with his/her house member & $290(47.4 \%)$ & $322(52.6 \%)$ \\
\hline Eating food prepared by an infected person & $277(45.3 \%)$ & $335(54.7 \%)$ \\
\hline Sharing eating tools and other house material & $612(100.0 \%)$ & $0(0.0 \%)$ \\
\hline Helping injured subjects with open wound & $578(94.4 \%)$ & $34(5.6 \%)$ \\
\hline Do you ask for screening of blood before transfusion & $612(100.0 \%)$ & $0(0.0 \%)$ \\
\hline Do you ask for a new syringe or sharps before use & $558(91.2 \%)$ & $54(8.8 \%)$ \\
\hline Have either attend a seminar or listen to a talk on HBV & $244(39.9 \%)$ & $368(60.1 \%)$ \\
\hline
\end{tabular}


IRA-International Journal of Applied Sciences

Table 5: Univariate analysis of association between Knowledge of HB and socio-demographic characteristics

\begin{tabular}{|c|c|c|c|c|c|c|}
\hline Characteristics & Indicators & Poor & Good & Excellent & $\chi^{2}$ & P value \\
\hline \multirow[t]{2}{*}{ Place } & Bamenda & $194(63.8 \%)$ & $101(32.2 \%)$ & $9(3.0 \%)$ & \multirow[t]{2}{*}{14.63} & \multirow[t]{2}{*}{0.001} \\
\hline & Ekona & $160(51.9 \%)$ & $141(45.8 \%)$ & $29(9.4 \%)$ & & \\
\hline \multirow[t]{2}{*}{ Sex } & Female & $151(44.0 \%)$ & $164(47.8 \%)$ & $28(8.2 \%)$ & \multirow[t]{2}{*}{61.15} & \multirow[t]{2}{*}{0.000} \\
\hline & Male & $203(75.5 \%)$ & $57(21.1 \%)$ & $9(3.3 \%)$ & & \\
\hline \multirow[t]{4}{*}{ Age group } & $<25$ years & $80(45.4 \%)$ & $86(48.9 \%)$ & $10(45.7 \%)$ & \multirow[t]{4}{*}{22.99} & \multirow[t]{4}{*}{0.001} \\
\hline & 25- 34 years & $117(59.1 \%)$ & $64(32.3 \%)$ & $17(8.6 \%)$ & & \\
\hline & $35-44$ years & $58(67.7 \%)$ & $31(25.0 \%)$ & $7(7.3 \%)$ & & \\
\hline & >44years & $99(66.9 \%)$ & $40(26.8 \%)$ & $3(6.3 \%)$ & & \\
\hline \multirow[t]{5}{*}{ Marital status } & Concubine & $12(54.5 \%)$ & $10(45.5 \%)$ & $0(0.0 \%)$ & \multirow[t]{5}{*}{5.49} & \multirow[t]{5}{*}{0.70} \\
\hline & Widow/er & $13(37.1 \%)$ & $21(60.0 \%)$ & $1(2.9 \%)$ & & \\
\hline & Divorced & $19(50.0 \%)$ & $15(39.5 \%)$ & $4(10.5 \%)$ & & \\
\hline & Single & $133(57.8 \%)$ & $80(34.8 \%)$ & $17(7.4 \%)$ & & \\
\hline & Married & $169(58.9 \%)$ & $103(35.9 \%)$ & $15(5.2 \%)$ & & \\
\hline \multirow[t]{6}{*}{ Occupation } & Farmer & $124(58.8 \%)$ & $81(38.4 \%)$ & $6(2.8 \%)$ & \multirow[t]{6}{*}{262.1} & \multirow[t]{6}{*}{0.00} \\
\hline & Civil servant & $18(51.4 \%)$ & $15(42.9 \%)$ & $2(5.7 \%)$ & & \\
\hline & $\begin{array}{l}\text { Medical } \\
\text { practitioners }\end{array}$ & $0(0.0 \%)$ & $2(10.0 \%)$ & $18(90.0 \%)$ & & \\
\hline & Student & $29(55.8 \%)$ & $22(42.3 \%)$ & $1(1.9 \%)$ & & \\
\hline & Trader & $16(50.0 \%)$ & $14(43.8 \%)$ & $2(6.2 \%)$ & & \\
\hline & Technician & $167(63.7 \%)$ & $87(33.2 \%)$ & $8(3.1 \%)$ & & \\
\hline \multirow{4}{*}{$\begin{array}{l}\text { Level of } \\
\text { education }\end{array}$} & None & $182(61.5 \%)$ & $104(35.1 \%)$ & $10(3.4 \%)$ & \multirow[t]{4}{*}{22.32} & \multirow[t]{4}{*}{0.00} \\
\hline & Primary & $64(60.9 \%)$ & $36(34.3 \%)$ & $5(4.8 \%)$ & & \\
\hline & Secondary & $101(56.4 \%)$ & $68(37.9 \%)$ & $10(5.5 \%)$ & & \\
\hline & Tertiary & $7(21.8 \%)$ & $13(40.6 \%)$ & $12(37.5 \%)$ & & \\
\hline \multirow[t]{5}{*}{ Income } & $<50,000$ frs & $150(61.7 \%)$ & $84(34.6 \%)$ & $9(3.7 \%)$ & \multirow[t]{5}{*}{19.48} & \multirow[t]{5}{*}{0.01} \\
\hline & $\begin{array}{l}50,000- \\
100,000 \text { frs } \\
\end{array}$ & $91(56.9 \%)$ & $61(38.1 \%)$ & $8(5.0 \%)$ & & \\
\hline & $\begin{array}{l}101,000- \\
150,000 \text { frs }\end{array}$ & $83(60.6 \%)$ & $45(32.8 \%)$ & $9(6.6 \%)$ & & \\
\hline & $>150,000 \mathrm{frs}$ & $8(30.8 \%)$ & $8(30.8 \%)$ & $10(38.4 \%)$ & & \\
\hline & $\mathrm{Na}$ & $22(47.8 \%)$ & $23(50.0 \%)$ & $1(2.2 \%)$ & & \\
\hline
\end{tabular}

Table 6: Univariate analysis of association between Attitude toward HB and socio-demographic characteristics

\begin{tabular}{|l|l|l|l|l|l|}
\hline Characteristics & Indicators & Negative & Positive & $\chi^{\mathbf{2}}$ & P value \\
\hline \multirow{2}{*}{ Place } & Bamenda & $211(69.4 \%)$ & $93(30.6 \%)$ & 140.2 & 0.000 \\
\cline { 2 - 4 } & Ekona & $67(21.8 \%)$ & $241(78.2 \%)$ & & \\
\hline Sex & Female & $15244.3(\%)$ & $191(55.7 \%)$ & 0.388 & 0.533 \\
\hline
\end{tabular}


IRA-International Journal of Applied Sciences

\begin{tabular}{|c|c|c|c|c|c|}
\hline & Male & $126(46.8 \%)$ & $143(53.2 \%)$ & & \\
\hline \multirow[t]{4}{*}{ Age group } & $<25$ years & $75(42.6 \%)$ & $101(57.4 \%)$ & \multirow[t]{4}{*}{0.83} & \multirow[t]{4}{*}{0.842} \\
\hline & 25- 34 years & $92(46.5 \%)$ & $106(53.5 \%)$ & & \\
\hline & $35-44$ years & $44(45.8 \%)$ & $52(54.2 \%)$ & & \\
\hline & $>44$ years & $67(47.2 \%)$ & $75(52.8 \%)$ & & \\
\hline \multirow[t]{5}{*}{ Marital status } & Concubine & $11(50.0 \%)$ & $11(50.0 \%)$ & \multirow[t]{5}{*}{2.297} & \multirow[t]{5}{*}{0.681} \\
\hline & Widow/er & $12(34.3 \%)$ & $23(65.7 \%)$ & & \\
\hline & Divorced & $16(42.1 \%)$ & $22(57.9 \%)$ & & \\
\hline & Single & $105(45.7 \%)$ & $125(54.3 \%)$ & & \\
\hline & Married & $134(46.7 \%)$ & $153(53.3 \%)$ & & \\
\hline \multirow[t]{6}{*}{ Occupation } & Medical practitioner & $7(35.0 \%)$ & $13(65.0 \%)$ & \multirow[t]{6}{*}{5.587} & \multirow[t]{6}{*}{0.348} \\
\hline & Trader & $11(34.4 \%)$ & $21(65.6 \%)$ & & \\
\hline & Civil servant & $19(54.3 \%)$ & $16(45.7 \%)$ & & \\
\hline & Student & $25(48.1 \%)$ & $27(51.9 \%)$ & & \\
\hline & Farmer & $89(42.2 \%)$ & $122(57.8 \%)$ & & \\
\hline & Technician & $127(48.5 \%)$ & $135(51.5 \%)$ & & \\
\hline \multirow{4}{*}{$\begin{array}{l}\text { Level of } \\
\text { education }\end{array}$} & None & $125(42.2 \%)$ & $171(57.8 \%)$ & \multirow[t]{4}{*}{2.996} & \multirow[t]{4}{*}{0.392} \\
\hline & Secondary & $88(49.2 \%)$ & $91(50.8 \%)$ & & \\
\hline & Primary & $48(45.7 \%)$ & $57(54.3 \%)$ & & \\
\hline & Tertiary & $17(53.1 \%)$ & $15(46.9 \%)$ & & \\
\hline \multirow[t]{5}{*}{ Income } & A50,000frs & $117(48.1 \%)$ & $126(51.9 \%)$ & \multirow[t]{5}{*}{3.739} & \multirow[t]{5}{*}{0.443} \\
\hline & $50,000-100,000 \mathrm{frs}$ & $66(41.2 \%)$ & $94(58.8 \%)$ & & \\
\hline & $101,000-150,000 \mathrm{frs}$ & $59(43.1 \%)$ & $78(56.9 \%)$ & & \\
\hline & $>150,000$ frs & $15(57.7 \%)$ & $11(42.3 \%)$ & & \\
\hline & $\mathrm{Na}$ & $21(45.7 \%)$ & $25(54.3 \%)$ & & \\
\hline
\end{tabular}


Table 7: Univariate analysis of association between Practice toward HB and socio-demographic characteristics

\begin{tabular}{|c|c|c|c|c|c|}
\hline Characteristics & Indicators & Bad & Good & $\chi^{2}$ & P value \\
\hline \multirow[t]{2}{*}{ Place } & Bamenda & $275(90.5 \%)$ & $29(9.5 \%)$ & \multirow[t]{2}{*}{71.90} & \multirow[t]{2}{*}{0.000} \\
\hline & Ekona & $188(61.0 \%)$ & $120(39.0 \%)$ & & \\
\hline \multirow[t]{2}{*}{ Sex } & Female & $253(73.8 \%)$ & $90(26.2 \%)$ & \multirow[t]{2}{*}{1.52} & \multirow[t]{2}{*}{0.218} \\
\hline & Male & $210(78.1 \%)$ & $59(21.9 \%)$ & & \\
\hline \multirow[t]{4}{*}{ Age group } & $<25$ years & $139(79.0 \%)$ & $37(21.0 \%)$ & \multirow[t]{4}{*}{6.98} & \multirow[t]{4}{*}{0.073} \\
\hline & $25-34$ years & $143(72.2 \%)$ & $55(27.8 \%)$ & & \\
\hline & $35-44$ years & $80(83.3 \%)$ & $16(16.7 \%)$ & & \\
\hline & $>44$ years & $101(71.1 \%)$ & $41(28.9 \%)$ & & \\
\hline \multirow[t]{5}{*}{ Marital status } & Concubine & $20(90.9 \%)$ & $2(9.1 \%)$ & \multirow[t]{5}{*}{10.07} & \multirow[t]{5}{*}{0.039} \\
\hline & Widow/er & $30(85.7 \%)$ & $5(14.3 \%)$ & & \\
\hline & Divorced & $26(68.4 \%)$ & $12(31.6 \%)$ & & \\
\hline & Single & $182(79.1 \%)$ & $48(20.9 \%)$ & & \\
\hline & Married & $205(71.4 \%)$ & $82(28.6 \%)$ & & \\
\hline \multirow[t]{6}{*}{ Occupation } & $\begin{array}{l}\text { Medical } \\
\text { practitioner }\end{array}$ & $5(25.0 \%)$ & $15(75.0 \%)$ & \multirow[t]{6}{*}{40.66} & \multirow[t]{6}{*}{0.000} \\
\hline & Trader & $27(84.4 \%)$ & $5(15.6 \%)$ & & \\
\hline & Civil servant & $21(60.0 \%)$ & $14(40.0 \%)$ & & \\
\hline & Student & $47(90.4 \%)$ & $5(9.6 \%)$ & & \\
\hline & Farmer & $159(75.4 \%)$ & $52(24.6 \%)$ & & \\
\hline & Technician & $204(77.9 \%)$ & $58(22.1 \%)$ & & \\
\hline \multirow[t]{4}{*}{ Level of education } & None & $250(84.5 \%)$ & $46(15.5 \%)$ & \multirow[t]{4}{*}{61.55} & \multirow[t]{4}{*}{0.000} \\
\hline & Secondary & $143(79.9 \%)$ & $36(20.1 \%)$ & & \\
\hline & Primary & $57(54.3 \%)$ & $48(45.7 \%)$ & & \\
\hline & Tertiary & $13(40.6 \%)$ & $19(59.4 \%)$ & & \\
\hline \multirow[t]{5}{*}{ Income } & $<50,000$ frs & $183(75.3 \%)$ & $60(24.7 \%)$ & \multirow[t]{5}{*}{14.66} & \multirow[t]{5}{*}{0.005} \\
\hline & $50,000-100,000$ frs & $128(80.0 \%)$ & $32(20.0 \%)$ & & \\
\hline & $\begin{array}{l}101,000- \\
150,000 \mathrm{frs} \\
\end{array}$ & $97(70.8 \%)$ & $40(29.2 \%)$ & & \\
\hline & $>150,000 \mathrm{frs}$ & $14(53.8 \%)$ & $12(46.2 \%)$ & & \\
\hline & $\mathrm{Na}$ & $41(89.1 \%)$ & $5(10.9 \%)$ & & \\
\hline
\end{tabular}

